\title{
PENGARUH KONSUMSI MINUMAN COKELAT HITAM TERHADAP PENURUNAN SKALA NYERI DISMENORE PRIMER
}

\author{
Wina Sriandini $^{*}$, Ari Damayanti ${ }^{2}$, Frengki Apriyanto ${ }^{3}$
}

${ }^{1,2,3}$ STIKES Widyagama Husada Malang

*Corresponding author:

Wina Sriandini

STIKES Widyagama Husada Malang

Email: andiniku10@gmail.com

\begin{abstract}
Primary dysmenorrhea giving an uncomfortable feeling in the lower abdomen which sometimes spread to the back waist and going along with headaches and nausea. That conditions can disrupt female university student's activities on the campus. Dark chocolate (Theobroma cacao) contains magnesium which can decrease primary dysmenorrhea pain. The objective of this research is to find out the effect of dark chocolate drink consumption in reducing primary dysmenorrhea pain in female university students of STIKES Widyagama Husada Malang. This study used quasy experimental design with one group pretest-posttest design. 53 respondents out of 84 population were taken by accidental sampling techniques. The instrument used in this study is observation sheet which contains Numeric Rating Scale (NRS). The pretest obtained the mean of primary dysmenorrheal pain $=6,396$. Posttest obtained the mean of primary dysmenorrhea pain $=1,566$. While for analysis results obtained the result of $p$ value $=0,000$ that means there is the effect of consumption dark chocolate drink in reducing primary dysmenorrhea pain in female university students of STIKES Widyagama Husada Malang. The Conclusion of this research there is the effect of dark chocolate drink consumption in reducing primary dysmenorrhea pain in female university students of STIKES Widyagama Husada Malang.

Keywords: Primary Dysmenorrhea; Dark Chocolate; Female.
\end{abstract}

\begin{abstract}
Abstrak
Dismenore Primer memberikan rasa tidak nyaman pada perut bagian bawah yang terkadang menjalar ke pinggang belakang dan disertai pusing dan mual sehingga dapat menggangu aktifitas mahasiswi di kampus. Cokelat Hitam (Theobroma cacao) mengandung magnesium yang dapat menurunkan nyeri dismenore primer. Tujuan dari penelitian ini adalah untuk mengetahui pengaruh konsumsi minuman cokelat hitam terhadap penurunan skala nyeri dismenore primer pada mahasiswi STIKES Widyagama Husada Malang. Metode pada penelitian ini menggunakan quasy eksperiment design dengan model one group pretest-posttest. Jumlah responden adalah 53 responden dari total populasi 84 responden. Teknik sampling yang digunakan yaitu Accidental Sampling. Instrumen yang digunakan yaitu lembar observasi skala nyeri dengan menggunakan Numeric Rating Scale (NRS). Hasil pretest diperoleh rata-rata skala nyeri dismenore primer yaitu 6.396, sedangkan hasil posttest diperoleh rata-rata penurunan skala nyeri dismenore primer yaitu 1.566. Nilai $\mathrm{p}$ value $0,000(<0,05)$ yang bermakna ada pengaruh konsumsi minuman cokelat hitam terhadap penurunan skala nyeri dismenore primer pada mahasiswi STIKES Widyagama Husada Malang. Dari penelitian ini dapat disimpulkan terdapat pengaruh konsumsi minuman cokelat hitam terhadap penurunan skala nyeri dismenore primer pada mahasiswi STIKES Widyagama Husada Malang.
\end{abstract}

Kata Kunci: Dismenore Primer; Cokelat Hitam; Wanita. 


\section{PENDAHULUAN}

Masa pubertas akan terjadi perubahan secara fisik, psikis, dan kematangan fungsi seksual ditandai datangnya menstruasi. Menstruasi merupakan hasil kinerja dari hipotalamus-hipofisis-ovarium. Menstruasi merupakan keadaan fisiologis yang terjadi pada wanita yang tidak mengalami kehamilan, tetapi kinerja kompleks hormon di dalam tubuh saat terjadi menstruasi mengakibatkan sebagian wanita mengalami nyeri pada perut bawah atau disebut dismenore primer.

Dismenore primer memberikan suasana tidak nyaman dibagian perut bawah, terkadang menjalar ke pinggang belakang, disertai pusing dan mual. sakit dapat dirasakan sebelum periode menstruasi dan berlangsung selama dua hari atau sampai akhir haid. Keadaan tersebut mengakibatkan kelemahan fisik dan mengganggu rutinitas sehari-hari yang mengakibatkan wanita di usia remaja hingga dewasa menjadi kurang produktif saat dismenore terjadi (Maharani, Pramono and Wahyuni, 2017).

Data dari WHO didapatkan kejadian dismenore di dunia rata-rata lebih dari $50 \%$ perempuan di setiap negara mengalaminya. Kejadian dismenore primer disetiap negara dilaporkan lebih dari 50\%. Penelitian di Amerika persentase kejadian dismenore sekitar $60 \%$, dan Swedia $72 \%$ (Wahyuningsih \& Sari, 2014). Di Indonesia 54,89\% perempuan menderita dismenore primer dan sisanya penderita dengan dismenore sekunder. Sedangkan di Jawa Timur angka kejadian dismenore sebesar $64,25 \%$ yang terdiri dari $54,89 \%$ dismenore primer dan 9,365 dismenore sekunder (Nurwana, Sabilu, \& Fachlevy, 2017).

Berdasarkan hasil studi pendahuluan peneliti pada mahasiswi di STIKES Widyagama Husada Malang tanggal 25-30 Maret 2019, didapat 84 mahasiswi mengalami dismenore primer. $23,8 \%$ mengalami nyeri ringan, $61,9 \%$ nyeri sedang, dan $14,36 \%$ nyeri berat. Selain mengeluh nyeri di bagian perut bawah, $80 \%$ disertai nyeri punggung bawah dan disertai keluhan lainnya seperti pusing, mual, dan nafsu makan menurun.

Terapi farmakologis yang dapat menurunkan nyeri dismenore primer adalah obat golongan nonsteroid antiinflammatory drugs (NSAIDs) contohnya seperti ibuprofen, namun tidak dianjurkan dikonsumsi dalam jangka waktu panjang karena dapat mengakibatkan gangguan pada gastrointestinal. Manajemen nyeri dengan terapi non farmakologis dapat menjadi alternatif pilihan untuk perempuan yang mengalami dismenore primer, untuk menghindari efek samping dari penggunaan obat farmakologis. Banyak peneliti yang telah melakukan penelitian dengan terapi non farmakologis, seperti kompres hangat, aroma terapi, dan beberapa penelitian yang memanfaatkan kekayaan alam, salah satunya dengan mengkonsumi cokelat hitam.

Cokelat hitam merupakan bahan dasar yang dapat dicampur dengan bahan lainnya menjadi berbagai produk makanan seperti kue, ice cream, minuman dan lain sebagainya. Meskipun cokelat mudah ditemukan dan banyak digemari oleh berbagai kalangan usia tetapi tidak banyak yang mengetahui kandungan cokelat yang memiliki banyak manfaat bagi kesehatan, salah satunya dapat mengurangi nyeri. Magnesium yang terkandung dalam cokelat hitam memiliki efek langsung terhadap tekanan vaskular dan dapat mengatur masuknya kalsium ke dalam sel otot polos uterus, sehingga magnesium mempengaruhi kontraksi dan relaksasi otot polos uterus. Magnesium dapat menekan peradangan dengan menghambat pembentukan prostaglandin (Maharani dkk., 2017). 


\section{METODE}

Penelitian ini menggunakan rancangan penelitian quasi eksperimen dengan model one group pre test and post test yaitu dengan mengukur rata-rata (mean) skala nyeri dismenore primer sebelum dan setelah diberikan minuman cokelat hitam. Populasi pada penelitian ini yaitu berjumlah 84 responden yang merupakan mahasiswi STIKES Widyagama Husada semester 2, 4, 6, dan 8 untuk Program Studi Pendidikan Ners dan Program Studi S-1 Kesehatan Lingkungan, serta semester 2, 4, dan 6 untuk Program Studi D-3 Ilmu Kebidanan yang mengeluh nyeri dismenore primer, kemudian diambil menggunakan teknik accidental sampling dan menghasilkan sampel sebanyak 53 responden dan termasuk kedalam kriteria inklusi penelitian.

Peneliti mengukur skala nyeri responden dengan menggunakan NRS (Numeric Rating Scale) segera saat responden melaporkan nyeri sebelum dilakukan intervensi. Peneliti memberikan minuman cokelat hitam campuran dari bubuk cokelat hitam siap saji 40 gram dan gula aren bubuk 40 gram (1:1) yang dicampur kedalam air panas $250 \mathrm{ml}$ kemudian dikonsumsi dalam keadaan hangat. Setiap responden diberikan intervensi dengan frekuensi yang berbeda, tergantung dari hasil posttest setelah intervensi pertama. Apabila hasil posttest pertama responden menunjukan skala nyeri antara skala nyeri 0-3 maka responden tidak dilakukan intervensi lagi.

Terapi dilakukan maksimal tiga kali untuk setiap responden. Setelah 30 menit dilakukan intervensi peneliti memberikan lembar observasi yang berisi NRS (Numeric Rating Scale) untuk menentukan skala nyeri setelah dilakukan intervensi berupa angka 0-10 tanpa mengkategorikkan skala tersebut, kemudian menghitung mean (nilai rata-rata) penurunan skala nyeri sesuai frekuensi terapi yang didapatkan untuk mengetahui pengaruh minuman cokelat hitam terhadap penurunan skala nyeri dismenore primer pada mahasiswi STIKES Widyagama Husada Malang.

Data yang telah didapatkan kemudian dianalisis dengan menggunakan uji hipotesis wilcoxon karena data berdistribusi tidak normal meskipun telah dilakukan transformasi.

\section{HASIL DAN PEMBAHASAN}

1. Gambaran Umum Tempat Penelitian

Penelitian ini dilaksanakan di masing-masing tempat tinggal responden yaitu di sekitar wilayah terdekat dari STIKES Widyagama Husada Malang.

2. Karakteristik Responden

Responden pada penelitian ini merupakan Mahasiswi STIKES Widyagama Husada yang mengalami dismenore primer yang diberikan terapi minuman cokelat hitam memiliki kisaran usia yang antara lain:

Tabel 1. Distribusi Usia, Usia Menarche, dan Skala Nyeri Dismenore Primer Responden

\begin{tabular}{cccc}
\hline Karakteristik & $\begin{array}{c}\text { Frekuensi } \\
(\mathbf{f})\end{array}$ & $\begin{array}{c}\text { Presentase } \\
(\%)\end{array}$ & Mean \\
\hline Usia Responden & & & \\
$18-21$ tahun & 24 & 45,3 \\
$22-25$ tahun & 29 & 54,7 & \\
\hline Usia Menarche & & & \\
$<12$ tahun & 31 & 58,5 \\
12-14 tahun & 13 & 24,5 & \\
$>14$ tahun & 9 & 17 & \\
\hline Skala Nyeri & & & \\
0 & 0 & 0 & \\
1 & 0 & 0 \\
2 & 0 & 0 \\
3 & 4 & 7,5 \\
4 & 4 & 7,5 \\
5 & 5 & 9,5 \\
6 & 17 & 32 \\
7 & 9 & 17 & \\
8 & 5 & 9,5 & \\
9 & 9 & 17 & \\
10 & 0 & 0 & \\
\hline Sumber: (Data Penelitian, 2019) & &
\end{tabular}

Tabel 1. menunjukan distribusi karakteristik responden berdasarkan usia saat ini, usia menarche dan skala nyeri dismenore primer sebelum diberikan terapi minuman cokelat hitam. Pada penelitian ini 
dismenore primer lebih banyak terjadi pada kelompok usia 22-25 tahun.

Selain itu kelompok usia menarche terbanyak yang mengalami dismenore primer adalah kelompok usia menarche $<12$ tahun. Pada tabel 1 menggambarkan hasil yang bervariasi dari skala nyeri sebelum responden mendapatkan terapi minuman cokelat hitam yang diukur dengan menggunakan NRS (Numeric Rating Scale). Dari 53 responden sebagian besar responden merasakan nyeri dismenore primer pada skala 6 dengan nilai rata-rata (mean) pretest yaitu 6,396, skala nyeri 6 termasuk dalam kategori tingkat nyeri sedang. Pada skala tersebut responden akan terasa kram pada perut bagian bawah, nyeri menyebar ke pinggang, sebagian aktivitas terganggu, dan mengalami kesulitan

\section{Pengaruh Konsumsi Minuman Cokelat Hitam}

Tabel 2. Hasil pengkuran skala nyeri dismenore primer sebelum (pretest) dan setelah (posttest) diberikan terapi minuman cokelat hitam

\begin{tabular}{lcccc}
\hline pengukuran & mean & Min & Max & Sig. (2- taild) \\
\hline Pretest & 6.396 & .0 & 3.5 & \multirow{2}{*}{$0,000(<0.05)$} \\
Posttest & 1.566 & .0 & 3.5 & \\
\hline
\end{tabular}

Sumber: (Data Penelitian, 2019)

Tabel 2. menyajikan data sebelum dan setelah diberikan terapi minuman cokelat hitam yang merupakan campuran dari bubuk cokelat hitam siap saji 40 gram dan gula aren bubuk 40 gram (1:1) yang dicampur kedalam air panas $250 \mathrm{ml}$. Sebelum diberikan terapi minuman cokelat hitam nilai mean skala nyeri dismenore primer dari 53 responden adalah 6,396 dan setelah diberikan terapi minuman cokelat hitam nilai mean menjadi 1,566 dengan nilai $p$ value yaitu $0,000<0,05$, sesuai dengan kaidah hipotesis penelitian jika $p$ value kurang dari 0,05 maka H0 ditolak yang berarti ada pengaruh konsumsi minuman cokelat hitam terhadap penurunan skala nyeri dismenore primer pada Mahasiswi di STIKES Widyagama Husada. Perbandingan skala nyeri dismenore primer sebelum dan setelah diberikan terapi cokelat hitam dapat dilihat dalam grafik berikut:

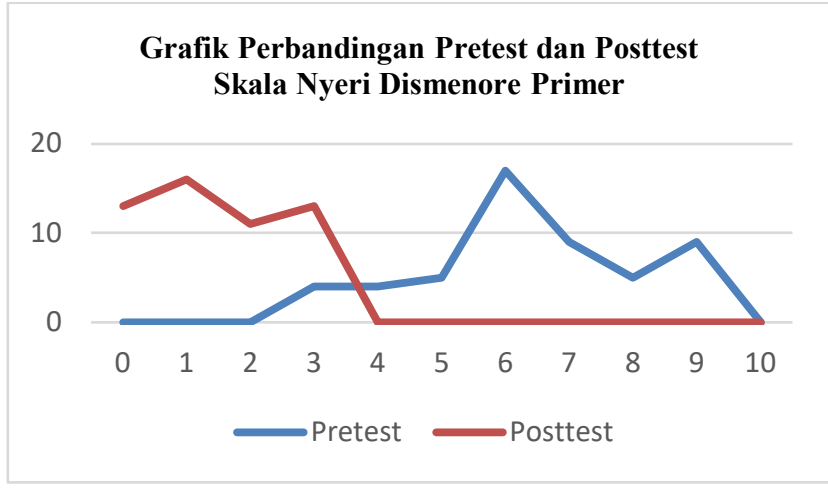

Gambar 1. Grafik Perbandingan Pretest dan Posttest Skala Nyeri Dismenore Primer

Dismenore primer adalah nyeri menstruasi yang dijumpai tanpa kelainan pada organ-organ genital. Dismenorea primer terjadi antara umur 15-25 tahun, dan akan berkurang seiring bertambahnya umur karena hormon yang dikeluarkan oleh organ reproduksi mulai stabil dan akan hilang setelah melahirkan (Anwar, 2011).

Dismenore primer dikaitkan dengan siklus ovulasi dan disebabkan oleh adanya prostaglandin yang diproduksi oleh endometrium pada fase sekresi yang menyebabkan kontriksi miometrium sehingga terjadi iskemia. Prostaglandin F2 $\alpha$ merupakan molekul yang berperan menstimulasi kontraksi uterus. Ditemukan peningkatan kadar prostaglandin di endometrium pada perempuan yang mengalami dismenore primer saat perubahan dari fase prolifeasi ke fase sekresi. Puncak peningkatan kadar prostaglandin terjadi pada 48 jam pertama menstruasi. Pada saat bersamaan muncul intensitas keluhan nyeri menstruasi disertai keluhan mual, muntah, nyeri kepala, atau diare yang disebabkan karena masuknya prostaglandin ke sirkulasi sistemik (Sukarni K \& P., 2013). 
Skala nyeri dismenore dapat diukur menggunakan beberapa instrumen seperti visual analog scales (VAS score), categorical scales, intial pain assesment tool, dan brief pain inventory. Tetapi numeric rating scale (NRS) sebagai pilihan skala pengukuran nyeri pengukurannya sederhana, lugas, dan mudah ditafsirkan (Shafikani, Gries, Trudeau, \& Reasner, 2018).

Berdasarkan hasil penelitian turunnya skala nyeri dismenore primer setelah mengkonsumi minuman cokelat hitam (Theobroma cacao) karena cokelat hitam mengandung magnesium. Magnesium terlibat dalam mengkatalisasi banyak reaksi biologis seperti menghambat transmisi impuls saraf penghantar nyeri dan relaksasi otot termasuk otot rahim.

Terapi farmakologis obat golongan nonsteroid antiinflammatory drugs (NSAIDs) dapat membantu menurunkan nyeri dismenore primer, tetapi obat golongan ini tidak dianjurkan untuk dikonsumsi dalam jangka waktu panjang sedangkan dismenore primer terjadi saat menstruasi yang memungkinkan wanita yang mengalami dismenore primer harus mengkonsumsi obat golongan nonsteroid antiinflammatory drugs (NSAIDs) setiap bulan saat terjadi nyeri.

Cokelat hitam memiliki efek yang sama dengan asam mefenamat (mefenamic acid) dan ibuprofen untuk mengurangi nyeri dismenore pada wanita dengan dismenore primer. Asam mefenamat (mefenamic acid) memiliki efek analgetik dan antipiretik yang cepat, yakni setelah 30 menit dan bertahan 3-6 jam (Wahyuni, 2018).

Magnesium terlibat dalam mengkatalisasi banyak reaksi biologis, termasuk sintesis protein, transmisi impuls saraf, relaksasi otot, produksi energi, dan adsorpsi tulang dan gigi. Cokelat adalah kaya akan magnesium (hingga 252,2 mg /100 g) dengan nilai yang mirip dengan roti dan kentang. Kakao mengandung 4-5 kali lebih banyak magnesium dari pada kacang polong, gandum putih, jagung dan beras (Cinquanta et al., 2016).

Kebutuhan magnesium pada remaja berdasarkan Kecukupan Gizi Rate (AKG) adalah 300 mg/hari. Dosis cokelat hitam sebanyak 40 gr mengandung cukup magnesium yaitu sebesar $115 \mathrm{mg}$ yang akan membantu meningkatkan jumlah magnesium dalam tubuh diperoleh dari makanan. Nyeri haid bisa diatasi dengan mengkonsumsi magnesium sebanyak $300 \mathrm{mg}$ selama sakit (Maharani, Pramono and Wahyuni, 2017).

Pada saat menstruasi terjadi, wanita akan kehilangan sejumlah mineral dan mikro dalam tubuh, salah satunya adalah magnesium. Cara untuk mengatasi dismnore primer tanpa efek samping adalah dengan mengontrol keseimbangan asupan mikronutrien yaitu vitamin dan mineral (Tih, Azaria, \& Gunadi, 2017).

Hasil penelitian ini sejalan dengan penelitian yang dilakukan oleh oleh Maharani dkk (2017) dengan judul “Dark Chocolate's Effect On Menstrual Pain In Late Adolescents" bahwa ada pengaruh yang signifikan pada terapi cokelat hitam terhadap penurunan tingkat nyeri haid pada remaja akhir 18-21 tahun. Hal tersebut terjadi karena efek langsung dari magnesium yang terkandung dalam cokelat hitam akan membantu untuk mengatur masuknya kalsium ke dalam sel otot polos di dalam tubuh, kalsium dibutuhkan untuk membantu pelepasan norepinefrin kemudian menempel di reseptor beta di uterus sehingga terjadi aktivasi protein kinase yang memfosforilasi suatu enzim yang berfungsi menahan kalsium keluar dari sarkoplasma dan melepaskan kalsium dari sitoplasma sehingga dapat mengurangi terjadinya kontraksi dan meningkatkan relaksasi otot polos rahim Maharani dkk (2017). 


\section{KESIMPULAN}

Minuman cokelat hitam dapat menurunkan skala nyeri dismenore primer karena magnesium yang terkandung dalam cokelat hitam terlibat dalam mengkatalisasi banyak reaksi biologis seperti menghambat transmisi impuls saraf penghantar nyeri dan relaksasi otot termasuk otot rahim. Minuman cokelat hitam dapat menjadi alternatif pilihan untuk mengatasi dismnore primer tanpa efek samping.

\section{UCAPAN TERIMA KASIH}

Terima kasih kami ucapkan kepada Lembaga Penelitian, Pengabdian Masyarakat dan Kewirausahaan (LPPM-K) STIKES Widyagama Husada Malang, mahasiswi dan tenaga didik di STIKES Widyagama Husada .

\section{DAFTAR RUJUKAN}

Maharani, S. I., Pramono, N., \& Wahyuni, S. (2017). Dark Chocolate's Effect on Menstrual Pain in Late Adolescent. Belitung Nursing Journal , 3(6):686- 692.

Wahyuni, L. T. (2018). Pengaruh Konsumsi Coklat Hitam Terhadap Penurunan Tingkat Nyeri Haid (Dismenore Primer) Pada Mahasiswi Ilmu Keperawatan STIKES Ranah Minang Padang, Menara Ilmu, XII(79), pp. 73-78.

Tih, F., Azaria, C., \& Gunadi, J. W. (2017). Efek Konsumsi Sulemen Kalsium dan Magnesium terhadap Dismenore Primer dan Sindrom Premenstruasi pada Perempuan Usia 19-23 Tahun. Global Medical and Health Communication, Vol. 5(3)159-166.

Nurwana, Sabilu, Y., \& Fachlevy, A. F. (2017). Analisis Faktor Yang Berhubungan Dengan Kejadian Disminorea Pada Remaja Putri . JIMKESMAS , (2) 6, 1-14.

Anwar, M., Baziad, A., \& Prabowo, P. (2011). Ilmu Kandungan. Jakarta: Bina Pustaka Sarwono Prawiroshardjo.

Sukarni K, I., \& P., W. (2013). Buku Ajar Keperawatan Maternitas. Yogyakarta: Nuha Medika.

Shafikani, S., Gries, K. S., Trudeau, J. J., \& Reasner, D. (2018). Response scale selection in adult pain measures: results from a literature review. Journal of Patient Reported Outcomes , 2(40) 19.

Wahyuni, L. T. (2018). Pengaruh Konsumsi Coklat Hitam Terhadap Penurunan Tingkat Nyeri Haid (Dismenore Primer) Pada Mahasiswi Ilmu Keperawatan STIKES Ranah Minang Padang, Menara Ilmu, XII(79), pp. 73-78.

Cinquanta, L. et al. (2016) 'Mineral essential elements for nutrition in different chocolate products', International Journal of Food Sciences and Nutrition.doi:10.1080/09637486.2016.1199664. 